\title{
Historic Industrial Fires and Their Influence on Contemporary Fire Protection
}

\author{
Robert Zalosh \\ Center for Firesafety Studies \\ Worcester Polytechnic Institute \\ Worcester, MA 01609, USA
}

\begin{abstract}
Brief accounts of five large industrial fires are presented to show how they stimulated advances in fire protection. The five fires reviewed are the 1911 New York City garment factory fire, the 1953 Livonia, Michigan automobile transmission factory fire, the 1977 Cologne, Germany automobile parts warehouse fire, the 1986 Basel, Switzerland chemical warehouse fire, and the 1987 Hinsdale, Illinois telephone exchange fire. Investigations and repercussions of these fires helped lead eventually to several key fire protection developments including: extensive revisions in and awareness of building egress and fire resistance requirements and capabilities, scientifically based laboratory flammability testing, significantly enhanced warehouse sprinkler protection, less hazardous flammable liquid containers, and improvements in the prevention and control of electrical cable fires.
\end{abstract}

KEY WORDS: historic fires, fire codes, industrial fires, fire protection technology

\section{INTRODUCTION}

Many important fire protection provisions were promulgated in the aftermath of major industrial fires. This paper reviews five historic industrial fires in order to relate how these fires influenced the development of important codes and standards, and also led to some key advances in fire protection technology. The five fires selected and the National Fire Protection Association standards and fire protection technologies they influenced are listed in chronological order in Table 1.

Three of the fires listed in Table 1 occurred in the United States and two occurred in Europe. Brief accounts of those fires and explanations of how they spurred specific fire technology developments form the main body of this paper. The author's textbook [1] provides a worldwide listing of large fatality and large monetary loss industrial fires and a more extensive discussion of the influence of various fires on specific industrial fire protection issues. The subjective selection of the five fires to be included in this paper is based in part on the availability of detailed information about the various fires. It is also based on the author's impressions of how these fires influenced the evolution of certain widely used codes/standards and fire protection technology as described in conversations and writings of some key members of the committees responsible for those standards. 
Table 1

Fires Discussed in Paper

\begin{tabular}{|c|c|c|c|c|}
\hline Date & Facility & Location & Pertinent NFPA Code & $\begin{array}{c}\text { Pertinent } \\
\text { Technology }\end{array}$ \\
\hline $\begin{array}{c}\text { March 25, } \\
1911 \\
\end{array}$ & $\begin{array}{l}\text { Garment } \\
\text { Factory }\end{array}$ & $\begin{array}{c}\text { New York } \\
\text { City }\end{array}$ & Life Safety Code & $\begin{array}{c}\text { Automatic Exit } \\
\text { Doors }\end{array}$ \\
\hline $\begin{array}{l}\text { August 12, } \\
1953\end{array}$ & $\begin{array}{l}\text { Automobile } \\
\text { Transmission } \\
\text { Plant } \\
\end{array}$ & $\begin{array}{l}\text { Livonia, } \\
\text { Michigan }\end{array}$ & $\begin{array}{l}\text { Roof Decks; Fire Tests } \\
\text { of Building Construction }\end{array}$ & $\begin{array}{l}\text { Flame Spread } \\
\text { Tests }\end{array}$ \\
\hline $\begin{array}{l}\text { October } \\
20,1977\end{array}$ & $\begin{array}{l}\text { Auto Parts } \\
\text { Warehouse }\end{array}$ & $\begin{array}{l}\text { Cologne, } \\
\text { Germany }\end{array}$ & $\begin{array}{l}\text { Sprinkler Systems, Rack } \\
\text { Storage of Materials }\end{array}$ & $\begin{array}{l}\text { Warehouse } \\
\text { Sprinkler } \\
\text { Technology } \\
\end{array}$ \\
\hline $\begin{array}{l}\text { November } \\
1,1986\end{array}$ & $\begin{array}{c}\text { Flammable } \\
\text { Liquid } \\
\text { Warehouse }\end{array}$ & $\begin{array}{c}\text { Basel, } \\
\text { Switzerland }\end{array}$ & Flammable Liquids Code & $\begin{array}{l}\text { Pressure- } \\
\text { Relieving } \\
\text { Containers } \\
\end{array}$ \\
\hline $\begin{array}{c}\text { May } 8, \\
1988\end{array}$ & $\begin{array}{l}\text { Telephone } \\
\text { Exchange }\end{array}$ & $\begin{array}{l}\text { Hinsdale, } \\
\text { Illinois }\end{array}$ & $\begin{array}{c}\text { Telecommunications } \\
\text { Facilities, } \\
\text { National Electrical Code }\end{array}$ & $\begin{array}{c}\text { Sensitive } \\
\text { Smoke } \\
\text { Detectors, } \\
\text { Nonthermal } \\
\text { Fire Damage } \\
\end{array}$ \\
\hline
\end{tabular}

\section{TRIANGLE SHIRTWAIST FACTORY FIRE}

The Triangle Shirtwaist Company operated a ladies garment factory on the top three floors of the 10-story Manhattan building shown in Figure 1. There were two stairways and elevators at opposite ends of each floor as shown in the ninth floor layout in Figure 2. However, the stairway doors opened in toward the work area because of limited space on each staircase landing. There was an external fire escape, but it ended at the second floor and was situated directly over a basement skylight in a completely enclosed courtyard. There was no automatic sprinkler system even though sprinkler systems were available in 1901 when the building was constructed. The following description of the workspace and the fire is based primarily on Leon Stein's 1962 book [2], and on Grant's 1993 paper [3].

There were between 200 and 275 workers on the eighth floor; some cut the cotton fabric for shirtwaists, and then would hang the cut fabric from wires stretched over the long tables. Garment scraps were discarded in bins under the tables. Other employees on the eighth floor worked at sewing machines.

Most of the sewing of the fabric pieces occurred on the ninth floor. There were about 240 sewing machines on $23 \mathrm{~m}$ long, $1.2 \mathrm{~m}$ wide tables as illustrated in Figure 2. The narrow aisle width $(0.76 \mathrm{~m})$ between tables was filled with a double row of chairs. The sewing machines were driven by leather belts connected to a flywheel on a rotating shaft in a trough between two tables. The shaft was powered by electric motors located at the Washington Place (south) end of the tables such that there was no aisle at the south end of the floor. The machines and motors were lubricated with oil stored in a barrel near the 
Greene St. exit door. Almost all of the 250 to 300 employees on the ninth floor were young women recently immigrated from overseas.

About 50 to 60 of the 500 to 600 Triangle Shirtwaist Company employees worked on the tenth floor, which was used for pressing and packaging garments, and for management offices. One of the staircases led to the roof, the other dead-ended on the $10^{\text {th }}$ floor. There were no fire drills or fire evacuation instructions. There were standpipe and hoselines supplied by a water tank on the building roof, and by a Fire Department connection at street level.

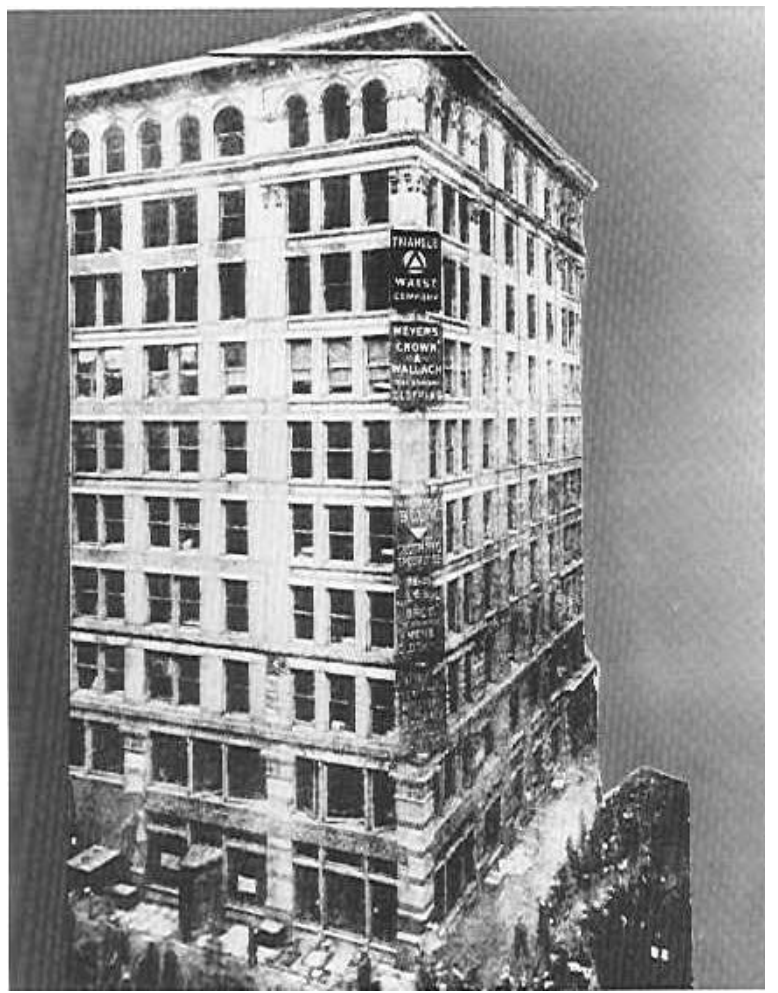

Figure 1. Triangle Shirtwaist Company occupied top three floors of the Asch building, photograph from Cornell University Kheel Center for Labor-Management Documentation and Archives 


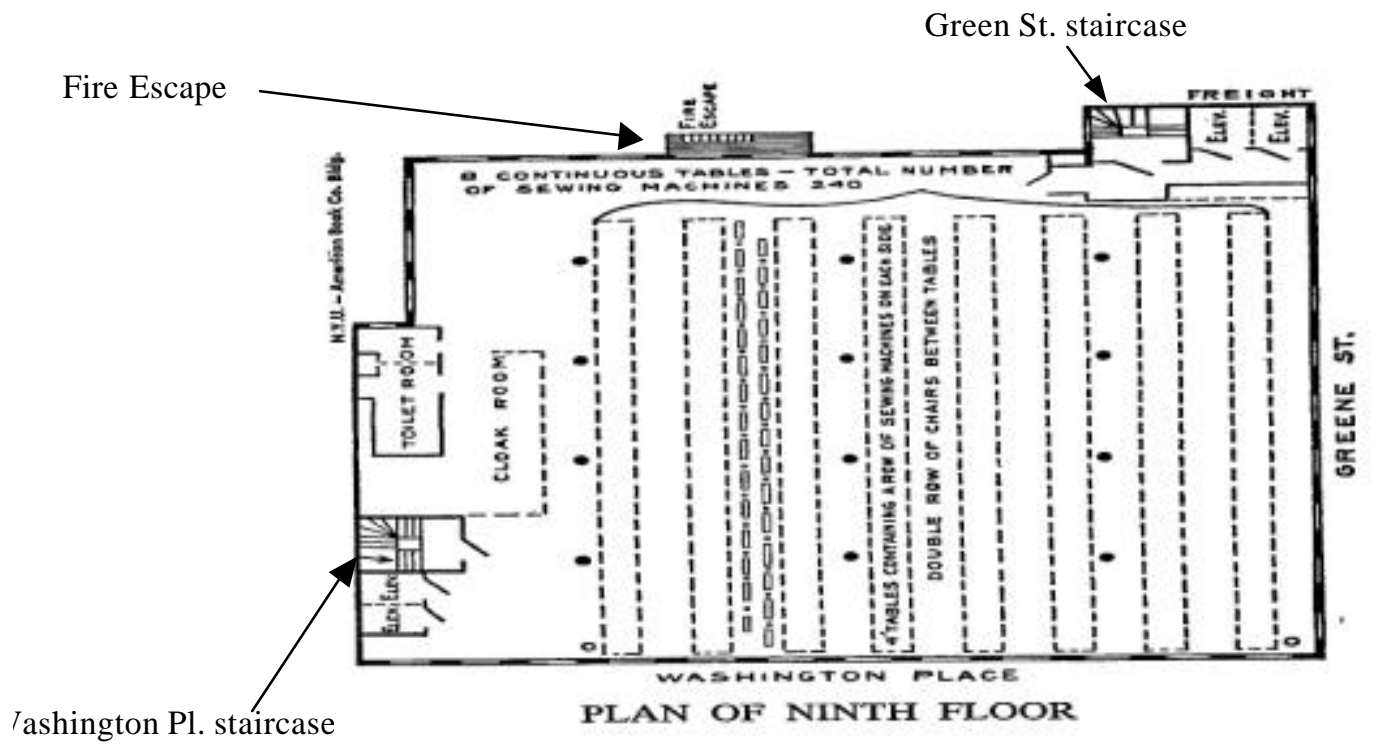

Figure 2. Triangle Shirtwaist Factory Floor; based on drawing from Stein [2].

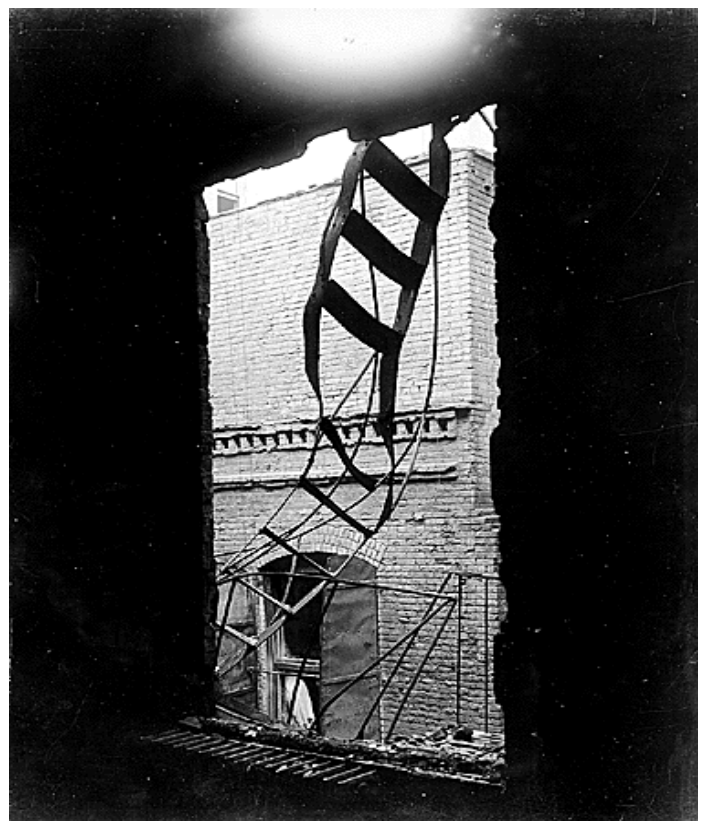

Figure 3. Triangle Shirtwaist fire escape ladder. Reproduced with permission from the Franklin D. Roosevelt Presidential Library. 
At 4:45 PM on March 25, 1911, the Triangle Shirtwaist fire started in a fabric scrap bin under the cutting tables on the eighth floor. Although New York Fire Department investigators could not definitively determine the ignition source, they suggested that a discarded cigarette was the most likely source. Flames from the scrap bin protruded up through slots in the cutting table and around the edges of the table and ignited the fabric and patterns on the table and the hanging garment pieces above the tables. When cutters noticed the fire, they made a futile attempt to extinguish it by throwing pails of water onto the burning fabric. They also tried in vain to get a water flow from the hoselines and standpipe, which was equipped with a valve in some unknown location. Meanwhile, burning cotton brands began flying around the room and landing on other tables where they ignited additional fabric. The combination of burning fire brands, flame radiation, and hot smoke accumulation under the ceiling allowed the fire to spread rapidly both along the tables and from table to table.

Eventually heat and pressure buildup caused the eighth floor windows to break. Pedestrians on the streets below heard "a big puff" as the windows popped. Flame spread to the ninth floor via the floor-to-ceiling windows and/or the Greene Street stairwell. Besides the fabric and wood tables, the lubricating oil on the ninth floor provided ample combustible loading for fire spread there also. A street level water pressure of about 1.4 MPa allowed fire fighter hose streams to reach the ninth floor, but ladders did not reach beyond the sixth floor.

Employee egress from the developing fire was severely restricted by several obstructions. The exit doors to the Washington Place stairway were locked and either the keyd were not available or were lost in the panic that ensued. Passage down the Greene Street stairway was limited by the $0.84 \mathrm{~m}$ stairway width with tapered turns, as well as by the inward opening door. Women attempting to flee via the fire escape ladder found they couldn't readily get below the second floor, and their cumulative weight overloaded and distorted the fire heated ladder as shown in Figure 3.

One hundred forty six workers perished in the Triangle Shirtwaist Company fire. Approximately half the fatalities were people who jumped from window ledges, mostly on the ninth floor. Nineteen bodies were found behind the locked exit door on the ninth floor. Other bodies were found on the fire escape and in the courtyard/basement below, on the stairway, and in the elevator shafts.

There were criminal trials, but the jury found the Triangle Shirtwaist owners not guilty of the manslaughter charge. Civil lawsuits ended with settlements of $\$ 75$ per family of the deceased, which is the equivalent of \$1233 in 2002 dollars. More importantly, public outrage over the working conditions that created the fire hazards, made it impossible to control the fire, and restricted escape, led to numerous changes in building and fire codes and strenghthened the burgeoning labor union movement.

The NFPA Committee on Safety to Life was formed in 1913. Two of the first Co mmittee projects were the writing of the 1916 NFPA report "Outside Stairs for Fire Exits," and the 1918 NFPA report "Safeguarding Factory Workers from Fire." According to the preamble to the current NFPA Life Safety Code [4], these reports "served as a groundwork for the present Code." The chapter on Industrial Occupancies in the current Life Safety Code includes required provisions for the following features pertinent to the Triangle Shirtwaist fire: exit doors, exit stairs, fire escape ladders, clear widths of exit pathways, and fire alarm systems. Exit door technologoical developments since the Triangle fire allow for doors to be locked providing they are equipped with a manual release device near the egress side of the door, and a sensor to automatically unlock when 
either an occupant approaches, a fire protective signalling system activates, or upon loss of power.

Despite the improved fire exit door technology and the many fire/building codes that specify egress requirements, restricted egress continues to be the most prevalent common factor in many multiple fatality industrial fires. One eggregious example is the 1993 toy factory fire in Thailand that resulted in the death of 188 factory workers [5]. Accounts of these tragic fires demonstrate that owner/management concern about employee theft and early departure motivates continuing violations and disregard of fire egress provisions. Thus, more than 90 years after the most publicized industrial fire of the twentieth century there is still a continuing need for the fire protection community to be vigilant and vigorous in promoting compliance with life safety codes and standards.

\section{LIVONIA, MICHIGAN AUTOMOBILE TRANSMISSION FACTORY FIRE}

If the Triangle Shirtwaist Company fire was the most important industrial fire of the twentieth century from the standpoint of worker safety, the General Motors automobile transmission factory fire was probably the most important industrial fire with regard to factory construction and business loss prevention. The GM transmission plant in Livonia, Michigan was an almost undivided building with a floor area of 140,000 $\mathrm{m}^{2}\left(1.4\right.$ million $\left.\mathrm{ft}^{2}\right)$ and a ceiling height of $6.4 \mathrm{~m}(21 \mathrm{ft})$. There were relatively small areas devoted to other manufacturing and to administrative offices, with only one fire wall separating the office area from the rest of the building.

The building construction consisted of a steel frame with exterior brick apron walls and an insulated steel deck roof. The roof insulation, which was an important factor in the fire, was asphalt-saturated felt covered by a tar and gravel outer surface. There was no insulation on the steel columns or the steel roof truss. The only sprinklered areas were the receiving, storage, and shipping areas around the periphery of the building, and the administrative offices at one end of the building. Production of automobile automatic transmissions entailed metalworking, heat treating (furnaces and quench tanks), and rustproofing, all operations involving combustible liquids or gases. According to the Fortune magazine story [6], there were 3,318 machines powered by 25,000 motors in the building at the time of the fire.

The fire outbreak at 3:50 PM on August 12, 1953 is illustrated in Figure 4. A cutting and welding crew was working on steam piping above an elevated conveyor ( $3.4 \mathrm{~m}$ above the floor) used to transport transmissions to and from a rustproofing dip tank. A drip pan under the conveyor had accumulations of the rustproofing liquid, which had a flash point of $37^{\circ} \mathrm{C}\left(98^{\circ} \mathrm{F}\right)$. Weld splatter fell into the drip pan and ignited the liquid. When the crew members at floor level saw the fire start, they handed carbon dioxide fire extinguishers to the welders on the ladder. The pan fire was almost extinguished at 3:54 PM when heat and smoke accumulating under the ceiling forced the men to descend from the ladder. Flames then began to spread over the entire $36.6 \mathrm{~m}(120 \mathrm{ft})$ length of the drip pan.

Flames from the drip pan ignited oily condensate on the steel roof truss. At 3:55 PM, the drip pan warped and spilled burning liquid onto the oil-soaked wood floor and the dip tank. In addition, the asphalt-saturated roof insulation ignited and dripped down through joints between the heat-deformed steel deck plates. The fire then spread over the roof and the oil coated equipment on the factory floor. Shortly later, electric cable shorted in conduits near the fire, and electric power was lost throughout the bulding. Livonia firefighters arriving at 4:05 PM could not see 
through the dense smoke in the building, and were not able to direct their hosestreams onto the fire. They could not prevent the collapse of the roof and the complete destruction of the manufacturing facility. The fire wall did prevent fire spread to the administrative offices.

There were six fatalities and property damage reported to be in the range $\$ 35$ million to $\$ 50$ million; the latter corresponding to $\$ 319$ million in 1990 dollars. Moreover, since the Livonia plant was the only G.M. automatic transmission manufacturing facility, production on the majority of G.M. automobiles was interrupted for several months. Business Week magazine stated that the Livonia fire and subsequent suspension and shifting of G.M. transmission production was the biggest business news story of 1953. The associated attention it received by the business community rendered fire protection an important consideration in the construction and renovation of large factories for many years to come.

According to the NFPA account [7] of the G.M. Livonia fire, major deficiencies in fire protection included the following:

1) The absence of fire walls and roof vents allowed uncontrolled fire and smoke spread throughout the plant and rapidly prohibited access for manual fire fighting within the building.

2) Inadequate sprinkler protection (only $20 \%$ of the plant was sprinklered) prevented fire control and suppression.

3) The automatic carbon dioxide system on the dip tank should have been extended to the drip pan, where manual fire fighting was difficult because of the pan elevation and length.

4) Unprotected and un-insulated structural steel columns, trusses, and decking promoted early roof collapse and fire spread via molten asphalt.

In 1954, General Motors announced [8] that all new G.M. manufacturing facilities were to include fire barriers in the form of fire walls, parapets, and draft curtains, and virtually $100 \%$ sprinkler protection supplemented by spray nozzles for dip tanks, quench tanks, and drip pans. Many other industrial organizations also adopted these new construction requirements for their new facilities.

The fire spread along the G.M. Livonia roof deck stimulated new fire testing to determine the flammability contributions of the various deck components. The socalled White House series of fire tests was conducted at Factory Mutual over the next several years to assess how asphalt loadings affected fire spread along the 3.05 $\mathrm{m}(10 \mathrm{ft})$ high, $30 \mathrm{~m}(100 \mathrm{ft})$ long roofs. At first these tests led to guidelines on the maximum allowable asphalt loadings $\left(0.58 \mathrm{~kg}\right.$-asphalt per $\left.\mathrm{m}^{2}\right)$ to prevent fire spread. However, it later became clear that other factors (such as insulation composition and thickness and the use of less flammable adhesives) also were pertinent factors, and that a smaller scale test was needed. Therefore, FM developed a construction calorimeter in which heat release rates were measured and correlated with the flame spread test results. In addition, Underwriters Laboratories started using the Steiner Tunnel test $(0.3 \mathrm{~m}$ wide by $7.6 \mathrm{~m}$ long) to make projections on flame spread criteria for large roof decks. These developments foreshadowed current small-scale heat release rate tests and laboratory flame spread tests. 


\section{COLOGNE AUTO PARTS WAREHOUSE FIRE}

Unlike the Triangle Shirtwaist factory and the G.M. Livonia factory, the Cologne automobile parts warehouse was a fully sprinklered building. The Ford Cologne warehouse fire is historic in that the fire overwhelmed the sprinkler system, and demonstrated the need for more effective warehouse sprinkler systems to cope with contemporary warehouse commodities and storage practices. The resulting research and development effort to develop such systems created a bona fide breakthrough in sprinkler technology.

The Ford Cologne warehouse in 1977 consisted of a 75,600 $\mathrm{m}^{2}\left(814,000 \mathrm{ft}^{2}\right)$ area and a $51,000 \mathrm{~m}^{2}\left(550,000 \mathrm{ft}^{2}\right)$ area separated by a double brick cantilevered fire wall. Building construction consisted of steel columns and beams supporting steel purlins

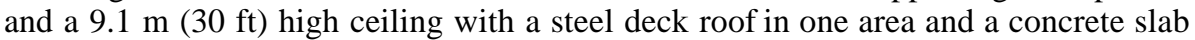
roof in another area. Ceiling sprinklers were $12.7 \mathrm{~mm}(0.50 \mathrm{in})$ orifice with a water supply as represented in Figure 6.

Storage in the area of fire origin included ABS plastic consoles, polyurethane foam padded steering wheels, rubber bladed windshield wipers, air filters (plastic and paper in cartons), and motor oil in small metal containers. Most of these commodities were stored in baskets stacked to a height of $5.8 \mathrm{~m}$ to $6.1 \mathrm{~m}$ (19 to 20 $\mathrm{ft}$ ). The water supply curve shown in Figure 6 satisfied the NFPA 231 requirements for a Class IV commodity, which was probably the appropriate classification for the original storage when the warehouse was built in 1962 and expanded in 1967. It does not satisfy the current NFPA sprinkler requirements [9] and CEN requirements for exposed plastic storage $6.1 \mathrm{~m}$ under a $9.1 \mathrm{~m}$ high ceiling, as indicated in Figure 6. 


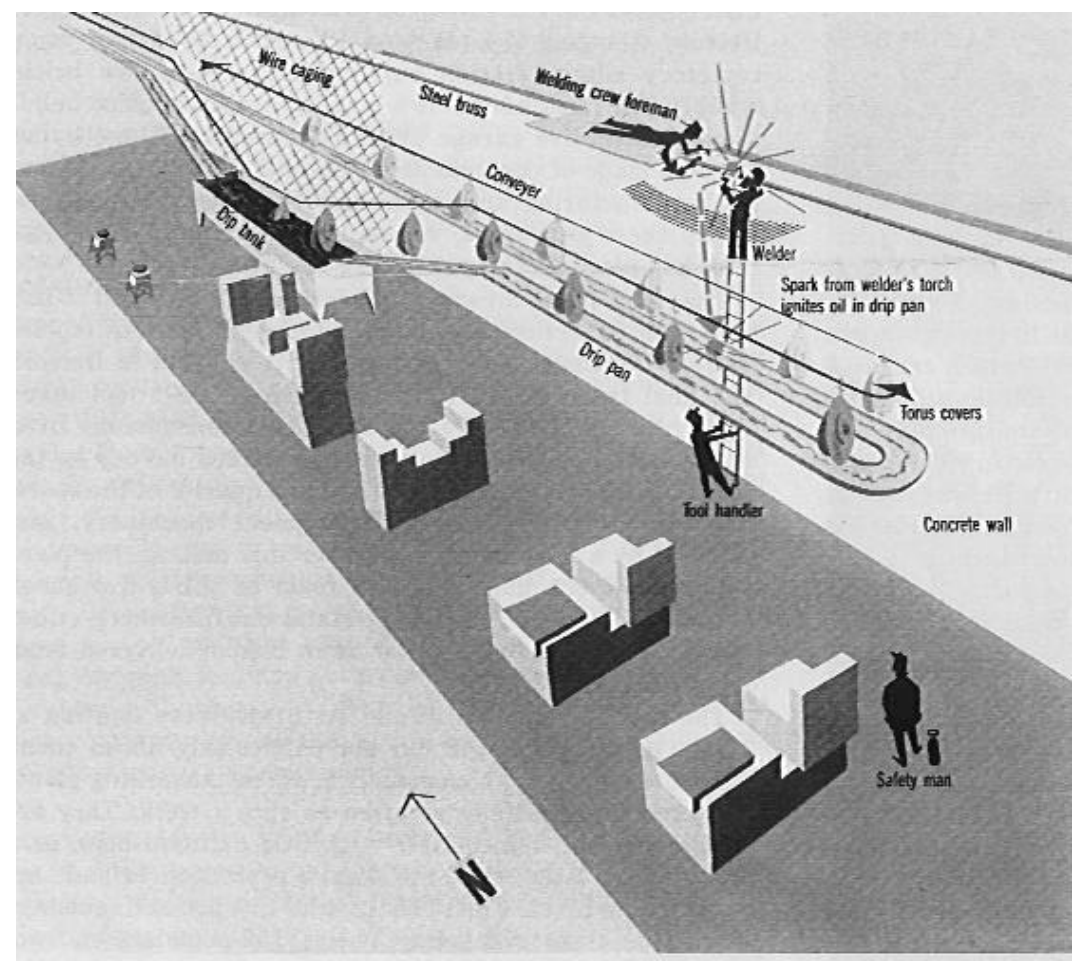

Figure 4. Initiation of GM Livonia Factory Fire, from Fortune article [6].

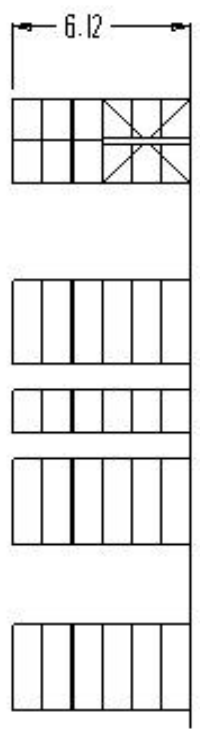

$11 \times 2.22 \mathrm{n}$

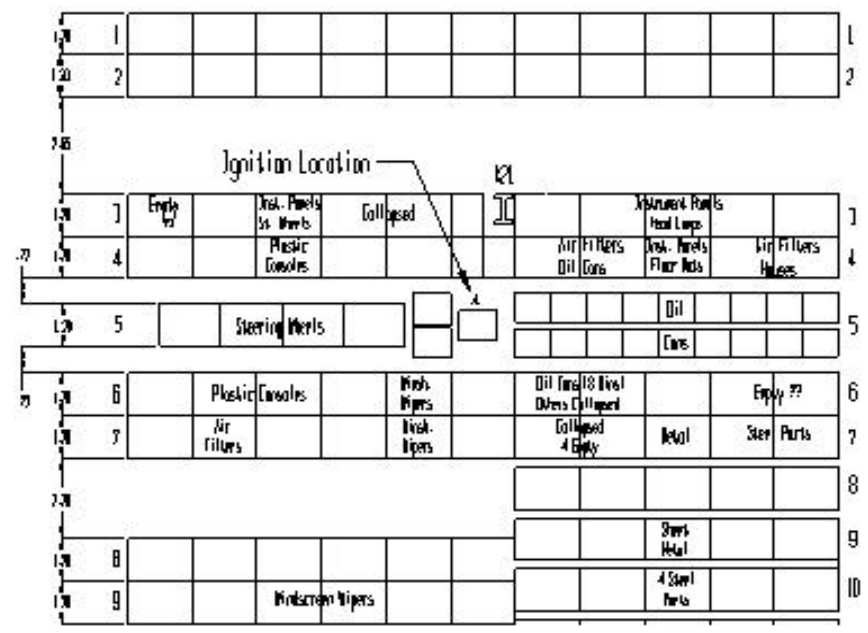

Figure 5 Area of Fire Origin in Cologne Warehouse Fire 


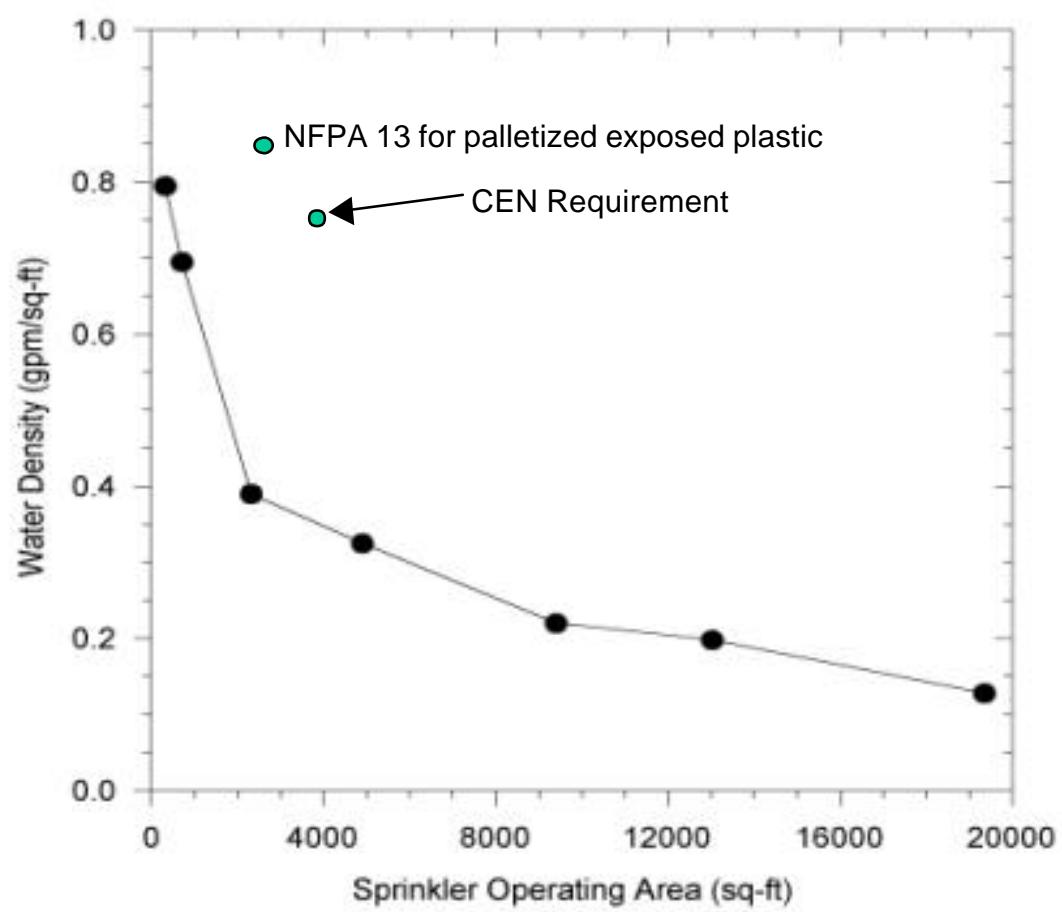

Figure 6 Water supply for Cologne Warehouse Fire

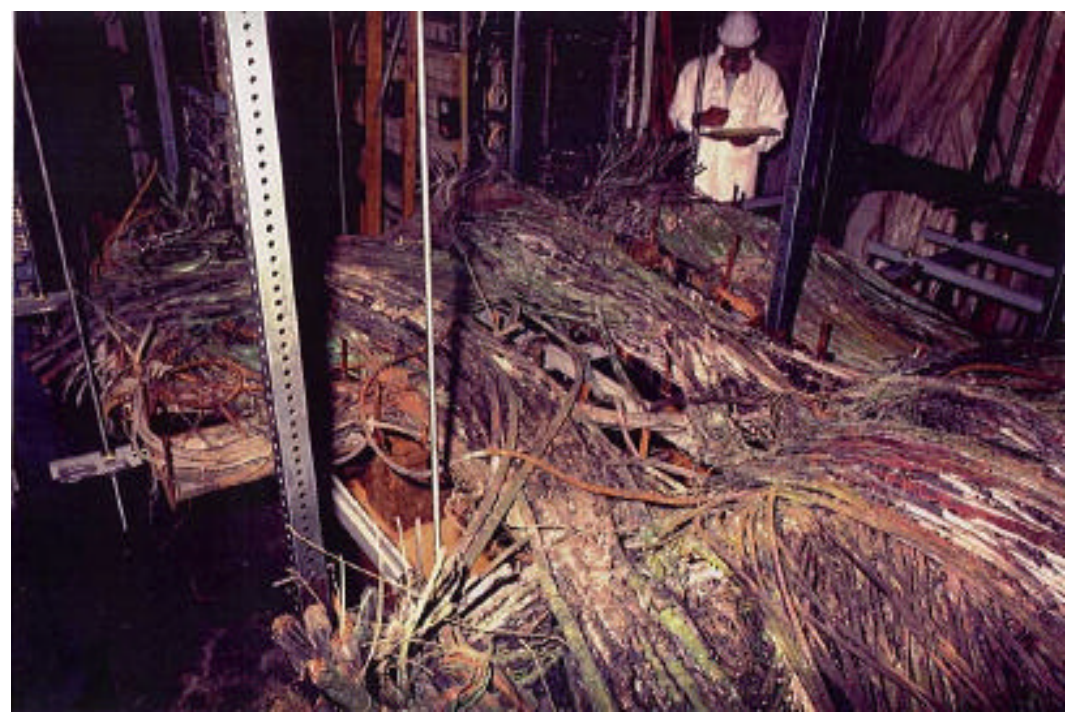

Figure 7. Burned cables in Hinsdale telephone exchange fire, reproduced with permission from FTI report [12]. 
The fire on October 20, 1977 started (probably by a discarded match or cigarette) in the vicinity of some plastic consoles stored in the aisles. Approximately four minutes after the fire started, a small hose stream was applied from a distance of $6 \mathrm{~m}$, but was not effective in controlling the growing fire. Five ceiling sprinklers were flowing five minutes after fire discovery, and about 24 heads were flowing two minutes later. The water pressure at this flow rate corresponded to a sprinkler discharge density of $16 \mathrm{~mm} / \mathrm{min}\left(0.40 \mathrm{gpm} / \mathrm{ft}^{2}\right)$, which is significantly lower than the density needed to control a $6 \mathrm{~m}$ high plastic commodity high. Eleven minutes after the start of the fire, the increasing number of open sprinklers reduced the discharge density to $6 \mathrm{~mm} / \mathrm{min}\left(0.15 \mathrm{gpm} / \mathrm{ft}^{2}\right)$.

The responding Ford fire brigade began discharging several hose streams and a dry chemical extinguisher toward the fire about nine minutes after fire discovery. However, the aisle and basket storage prevented the hose streams from effectively reaching the area of active burning. Smoke in the fire area prevents direct viewing of the fire. Electric cables needed for a fire pump, for roof smoke ventilators, and for building lights shorted out approximately twenty minutes after fire discovery. Approximately ten minutes later, flames emerged from a hole in the roof. Firefighters inside the warehouse heard metal cans of oil bursting at this time, i.e. 30 minutes after fire start. The roof collapsed about 75 minutes after fire initiation. The fire eventually destroys the area of the warehouse on one side of the fire wall, but does not penetrate across the fire wall.

One primary cause of the sprinkler system failing to control this fire is the inadequate sprinkler discharge flow rate as numerous sprinklers actuated. Another important limitation of the sprinkler discharge is the small drop size produced from the $12.7 \mathrm{~mm}$-orifice sprinkler head. It is very difficult for these small drops to penetrating the upward flowing fire plume and reach the burning commodity. In the years following this fire, Factory Mutual research personnel began developing larger orifice sprinklers. As a result of this research and development, the $16.3 \mathrm{~mm}$ diameter Large Drop sprinkler became commercially available in the early 1980s, and the first $17.8 \mathrm{~mm}$ diameter Early Suppression Fast Response (ESFR) sprinkler became commercially available several years later. Most warehouse storage sprinkler systems being designed and installed now in North America utilize these and other larger orifice sprinkler heads.

\section{HINSDALE TELEPHONE EXCHANGE FIRE}

The Hinsdale telephone exchange fire in May 1988 was one of several important electrical cable fires that demonstrated the difficulties of extinguishing burning cables while they remain energized. Similar difficulties had been experienced in 1975 during the Browns Ferry nuclear plant fire [10] and the New York Telephone fire [11]. The Hinsdale fire was selected for description in this paper because it occurred at a time when the fire protection community was trying to deal with changes associated with the advent of newly commercialized sensitive smoke detection technology, with the impending unavailability of halon suppression systems, and with the realization that corrosive combustion products can produce extensive electrical equipment damage even in relatively small fires.

In May 1988, critical switching equipment at the Hinsdale, Illinois central office telephone exchange was located in a large open area next to densely packed elevated cable trays suspended approximately $0.6 \mathrm{~m}(2 \mathrm{ft})$ below the $4.3 \mathrm{~m}(14 \mathrm{ft})$ high 
ceiling. Electric utility power lines entered a transformer vault in the building basement where the voltage was stepped down and converted to the 48 volt direct current power supply for the switches, and to other dc voltage levels needed for other equipment. Since the uninterrupted power supply of the switches was a primary concern, there were two backup power supplies. If and when the electric utility power supply failed, a standby battery power system would startup automatically and then allow two diesel powered generators to startup and provide the needed power.

The two-story high building is constructed with concrete columns and beams, with masonry walls and concrete floor slabs. There were spot smoke detectors on the ceiling, with the alarm signal transmitted to a telephone company monitoring station about $320 \mathrm{~km}$ (200 miles) away from Hinsdale. There was no automatic fire suppression system in the building.

Sunday, May 8, 1988 was Mother's Day with the associated extremely high level of telephone calls passing through the Hinsdale central office. The building was not occuppied; the last employee having departed about an hour before the fire started. The first indication of the fire was a series of power interruption and smoke detector alarms transmitted to the telephone compnay monitoring station at 3:50 PM. Personnel at the monitoring station misinterpreted the alarms as being due to power outages caused by high wind conditions. They observed indications that the backup power systems were starting up and functioning. They waited until 4:16 PM to notify the Hinsdale area office supervisor of the power failure and fire alarm signals.

At 4:24 PM (a minute after the monitoring station receives signals indicating multiple equipment malfunctions), the Hinsdale office supervisor reaches the technician on duty and directs him to investigate the alarms. A few minutes later the office supervisor attempted to call the Hinsdale Fire Department, but by then local telephone service was not functioning. When the telephone company technician arrived at the Hinsdale central office at 4:52 PM, he observed heavy smoke at ceiling level in the area around the switching equipment. After unsuccessfully trying to call the Hinsdale Fire Department, he leaves the building and asks a motorist to drive to the Fire Department to report the fire.

The Hinsdale Fire Department arrived at the telephone exchange at 5:02 PM, 72 minutes after the first fire alarm. Despite the heavy smoke throughout most of the first floor, fire fighters did see a small fire in some equipment under the elevated cable trays. They successfully extinguished the small equipment fire and started directing hose streams onto the burning cable trays when they had to leave because of diminshed air supplies in their self contained breathing apparatus. Other fire fighters entered and directed hose streams toward the burning cable trays, but the fire would repeatedly re-ignite and spread after being temporarily suppressed. Extinguished attempts with dry chemical extinguishers were equally unsuccessful.

During the period from 5:50 PM until 7:15 PM, there were numerous futile attempts to shut off electrical power to the burning cables. However, electrical arcing and burning continued in the overhead cables. Finally, at 7:15 PM, the remaining electrical circuit fuses in the basement to de-energize the cables. At this point the fire is readily extinguished except for some residual burning of cable jacketing.

Figure 7 shows the lowered cable trays during the fire investigation. There was a random mix of burned power and communication cables that had been installed over a period of thirty years prior to the fire. Based on the physical evidence and 
numerous fire simulations, investigators [12] concluded that the 1988 Hinsdale fire was probably started by a short circuit due to electrical contact between a power cable with damaged insulation and the grounded metal sheath of an armo red cable. They hypothesized that the short was of insufficient current to trip circuit fuses, but generated sufficient heat to ignite adjacent cable insulation. The insulation damage was judged to have occurred two months before the fire when some obsolete cables were removed from the densely packed trays. The fire break out on May $8^{\text {th }}$ was presumably due to the unusually high telephone usage that day.

Reports of the Hinsdale fire and its cause stimulated several important changes in both the telecommunications industry and the fire protection community. Telephone companies revised the power controls in their telephone exchanges to facilitate rapidly de-energizing electrical equipment when needed. They also provided redundant switching capability to avoid the extensive telephone service outages in the weeks following the Hinsdale fire. In additon the fire motivated revisions to the U.S. National Electrical Code that created new categories of reduced cable flammability, required removal of unused cable from trays, and prohibited the random mixing of power cable and signal cable in cable trays. The fire also rejuvenated interest and funding for cable flammability testing, more sensitive and more reliable smoke detection, and new clean agent fire suppression agents. These important developments have allowed for improved fire protection at many industrial facilities with critically needed electric cable runs and electrical equipment.

\section{BASEL 1986 CHEMICAL WAREHOUSE FIRE}

The 1986 Sandoz chemical warehouse fire in Basel, Switzerland received worldwide attention because of the resulting environmental damage along the Rhine River. It raised awareness to the need of dealing with flammable liquid and hazardous material fires while discharging only a limited amount of fire fighting water and containing the resulting contaminated runoff. This awareness has caused many responding fire chiefs to refrain from discharging large hose streams onto burning industrial facilities with flammable liquids and chemicals. Along with the 1987 Dayton, Ohio flammable liquid warehouse fire [13], the 1986 Basel fire motivated important fire test projects that resulted in extensive changes to flammable liquid warehouse fire protection.

Building 956 at the Sandoz plant on the Rhine River near Basel was $90 \mathrm{~m}$ long, $50 \mathrm{~m}$ wide, and had two sections divided by a brick wall as illustrated in Figure 8 . It had a structural steel frame with a $12 \mathrm{~m}$ high twin peaked roof made from corrugated asbestos cement panels. There was neither an automatic fre detection nor an automatic fire suppression system, but there was an on-site fire brigade headed by a fire chief who had a residence on the plant site.

On October 31, 1987, chemical storage in the warehouse included the following [14]: organophosphate insecticide, phenyl-urea derivative and dinitrocresol derivative weed controls, water soluble organic mercury compounds, various formulating agents, and miscellaneous agrochemicals including zinc phosphide. Some of these chemicals were powders or pellets stored in bags or drums. Others were flammable liquids with flash points of $30^{\circ} \mathrm{C}$ and higher stored in drums on pallets to heights up to $10 \mathrm{~m}$. 
Warehouse operations on October 31, 1986 included shrink wrapping paper sacks of product on pallets. Apparently, a flame heat source for the shrink wrapping process ignited a sack of powdered pigment, and the pigment started smoldering without being noticed by the workers. At 12:19 AM on November 1, 1986, a fire was observed when flames started shooting through the roof of the warehouse.

The fire brigade was immediately notified, and the brigade chief arrived at the warehouse at 12:22 AM. Although his first inclination was to allow the warehouse to burn because of the already extensive fire spread, he changed his opinion when metal drums started rocketing through the roof and threatening nearby buildings containing large quantities of organic solvents and other chemicals. Attempts to suppress the fire with foam proved futile. The fire brigade then discharged large hose streams in an attempt to cool the exposed steel drums in the warehouse. The estimated total water discharge rate was $30 \mathrm{~m}^{3}$ per minute $(8000 \mathrm{gpm})$ during this period. The fire was declared out at $5 \mathrm{AM}$ on November $1^{\text {st }}[14,15]$.

The runoff into the Rhine River from mercury compounds and other toxic chemicals caused an extensive kill of eels and other fish and vegetation. Chemical deposits on the riverbed had to be dredged, and the fish restocked. Fortunately, the biological recovery was swift and hopefully permanent. However, the chemical companies in Basel vowed to prevent any future fire water runoff induced environmental nearcatastrophe by constructing two extremely large catch basins, one with a $15000 \mathrm{~m}^{3}$ capacity, and the other with a $2500 \mathrm{~m}^{3}$ capacity.

Since the 1986 Basel warehouse fire, there have been important revisions to flammable liquid codes, such as NFPA 30 [16], requiring extensive drainage and containment provisions to cope with the expected water runoff. There have also been extensive fire test programs to determine effective automatic sprinkler protection for liquid warehouses. These tests have involved flammable liquid containers of various sizes and types including metal drums. One of the benefits of these tests has been the demonstration that thermally-sensitive pressure-relieving devices on metal drums can prevent the drum/container rocketing that was such an important factor in the Sandoz Basel fire. NFPA 30 now provides an incentive to utilize these pressure-relieving devices by allowing for less stringent automatic sprinkler protection in flammable liquid warehouses where they are used. Implementation of the NFPA 30 and similar guidelines will instill confidence that we are much better prepared to deal with fires in large chemical warehouses.

\section{Conclusions}

Many contemporary fire protection practices stem in large part from lessons learned from the five important industrial fires reviewed in this paper. These practices include scientifically based laboratory flammability testing, fire resistive industrial building construction, advanced automatic sprinkler protection for warehouse storage, effective egress provisions using automatic exit doors, improved fire prevention for electrical cables and equipment, and the use of more sensitive smoke detection and clean suppression agents.

Continued advances in industrial fire protection can be facilitated thorough scientifically valid, widely disseminated documented investigations of large loss fires. At the same time, it is important to continue the widespread dissemination of 


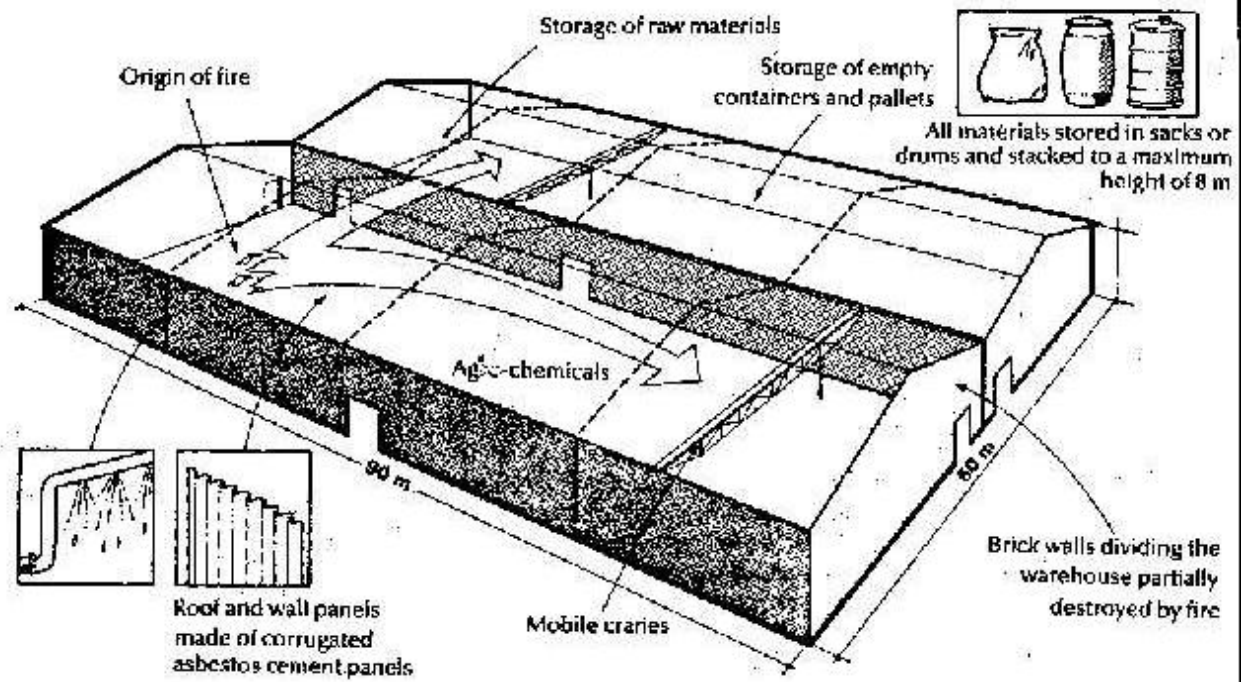

Figure 8. Storage and fire progression in Sandoz chemical warehouse (reproduced from Fire Prevention, 1987).

the previously learned lessons to minimize the tendency for historic fires like these to reoccur in other facilities with similar gaps or defects in fire protection.

\section{REFERENCES}

1. Zalosh, R., Industrial Fire Protection Engineering, John Wiley and Sons Ltd, scheduled for publication, 2003.

2. Stein, L., The Triangle Fire, Lippincott, 1962.

3. Grant, C., "Triangle Fire Stirs Outrage and Reform," NFPA Journal, pp. 72-82, May/June 1993.

4. NFPA 101" , "Life Safety Code," National Fire Protection Association, 2000 Edition.

5. Grant, C. and Klem, T., "Summary Investigation Report: Kader Industrial (Thailand) Co. Ltd., Nakhon Province, Thailand, May 10, 1993, NFPA, 1993.

6. Harris, W.B., "The Great Livonia Fire," Fortune, pp. 132-135, 172-177, November 1953.

7. "The General Motors Fire," Quarterly of the NFPA, October 1953.

8. "How to Prevent Large-Loss Fires in Factories," Engineering News Record, pp. 28-30, July 15, 1954.

9. NFPA 13, "Standard for the Installation of Sprinkler Systems," National Fire Protection Association, 2002 Edition.

10. Pryor, A., “The Browns Ferry Nuclear Plant Fire," SFPE Technical Paper, 1976.

11. Lathrop, J., “Telephone Exchange Fire,” Fire Journal, July 1975. 
12. FTI Report, "Hinsdale Central Office Fire," Joint Report of the State Fire Marshall and Illinois Commerce Commission Staff, Forensics Technologies International Corporation, 1989.

13. Isner, M., “\$49 Million Loss in Sherwin-Williams Fire,” Fire Journal, 65, 1988.

14. "Schweizerhalle, the Fire on November 1, 1986 and Its Aftermath," 1987 Sandoz report graciously provided by Dr. George Suter.

15. “The Aftermath of the Sandoz Fire,' Fire Prevention, No. 199, May 1987.

16. NFPA 30, "Flammable AND Combustible Liquids Code," National Fire Protection Association, 2000 Edition. 